\title{
Trend Analysis of Aerosol Optical Depth and Ångström Exponent Anomaly over East Africa
}

\author{
John W. Makokha1 ${ }^{*}$, Jared O. Odhiambo1', Juma S. Godfrey ${ }^{2}$ \\ ${ }^{1}$ Department of Science Technology and Engineering, Kibabii University, Bungoma, Kenya \\ ${ }^{2}$ Department of Mathematics, Kibabii University, Bungoma, Kenya \\ Email: ^shemmax@students.uonbi.ac.ke, godfrey.juma@kibu.ac.ke, godfrey.juma2@gmail.com
}

How to cite this paper: Makokha, J.W., Odhiambo, J.O. and Godfrey, J.S. (2017) Trend Analysis of Aerosol Optical Depth and Ångström Exponent Anomaly over East Africa. Atmospheric and Climate Sciences, 7, 588-603.

https://doi.org/10.4236/acs.2017.74043

Received: October 5, 2017

Accepted: October 28, 2017

Published: October 31, 2017

Copyright $\odot 2017$ by authors and Scientific Research Publishing Inc. This work is licensed under the Creative Commons Attribution International License (CC BY 4.0).

http://creativecommons.org/licenses/by/4.0/
Abstract

Trend analysis of atmospheric aerosols enhances confidence in the evaluation of both direct and indirect effects of aerosols on regional climate change. To comprehensively achieve this over East Africa, it's important to understand aerosols temporal characteristics over well selected sites namely Nairobi $\left(1^{\circ} \mathrm{S}\right.$, $\left.36^{\circ} \mathrm{E}\right)$, Mbita $\left(0^{\circ} \mathrm{S}, 34^{\circ} \mathrm{E}\right)$, Mau Forest $\left(0.0^{\circ} \mathrm{S}-0.6^{\circ} \mathrm{S} ; 35.1^{\circ} \mathrm{E}-35.7^{\circ} \mathrm{E}\right)$, Malindi $\left(2^{\circ} \mathrm{S}, 40^{\circ} \mathrm{E}\right)$, Mount Kilimanjaro $\left(3^{\circ} \mathrm{S}, 37^{\circ} \mathrm{E}\right)$ and Kampala $\left(0^{\circ} \mathrm{N}, 32.1^{\circ} \mathrm{E}\right)$. In this context, trend analysis (annual (in Aerosol Optical Depth (AOD) at 550 $\mathrm{nm}$ and Ångström Exponent Anomaly (ÅEA) at 470 - $660 \mathrm{~nm}$ ) and seasonal (AOD)) from Moderate Resolution Imaging Spectroradiometer (MODIS) were performed following the weighted least squares (WLS) fitting method for the period 2000 to 2013. The MODIS AOD annual trends were ground-truthed by AErosol RObotic NETwork (AERONET) data. Tropical Rainfall Measurement Mission (TRMM) was utilized to derive rainfall rates (RR) in order to assess its influence on the observed aerosol temporal characteristics. The derived annual AOD trends utilizing MODIS and AERONET data were consistent with each other. However, monthly AOD and RR were found to be negatively correlated over Nairobi, Mbita, Mau forest complex and Malindi. There was no clear relationship between the two trends over Kampala and Mount Kilimanjaro, which may imply the role of aerosols in cloud modulation and hence RR received. Seasonality is evident between AOD and $\AA E A$ annual trends as these quantities were observed to be modulated by RR. AOD was observed to decrease over East Africa except Nairobi during the study period as a result of RR during the study period. Unlike the other study sites, Nairobi shows positive trends in AOD that may be attributed to increasing populace and fossil fuel, vehicular-industrial emission and biomass and refuse burning during the study period. Negative trends over the rest of the study sites were associated to rain washout. The AOD and ÅEA derived annual trends were found to meet the statistical significance of $95 \%$ confidence level over each 
study site.

\section{Keywords}

East Africa, MODIS, Aerosol Optical Depth, Angstrom Exponent, Trend Analysis

\section{Introduction}

Atmospheric aerosols influence the Earth's atmospheric energy budget and therefore climate through direct and indirect means (Intergovernmental Panel on Climate Change) [1] [2]. Aerosols directly influence climate by absorbing and scattering solar radiation which yields a warming and cooling effect, respectively on the immediate atmosphere. Likewise, aerosols indirectly modify the properties of clouds by acting as Cloud Condensation Nuclei (CCN) that aid in the formation of clouds. The complex nature of atmospheric aerosols both spatially and temporally together with their short lifetime enhances uncertainties in the quest to estimate their direct and indirect effects on climate forcing.

Understanding the spatial and temporal variability of atmospheric aerosols on both regional and global scales requires long-term satellite measurements of high fidelity, from which we can then evaluate aerosol effects in climate models [3] [4] [5]. To enhance accuracy in the calculated regional and global aerosol trends, we utilized satellite data from MODIS to assess the utility of east Africa's atmospheric aerosol properties in the accurate estimation of regional climate trends/models.

Aerosol Optical Depth (AOD) annual trends over worldwide stations utilizing the Sea-viewing Wide Field-of-view Sensor (SeaWiFS) from 1998-2010 have been quantified i.e. $0.00078 \pm 0.00019 \mathrm{yr}^{-1}$ with an absolute trend relative to its uncertainty $\left(\left|\omega / \sigma_{\omega}\right|\right)$ of 4.00000 at $95 \%$ confidence level [6]. Nevertheless, on regional scale for example the dust prone region of Arabian Peninsula experiences a strong positive AOD trend of $0.00920 \pm 0.00130 \mathrm{yr}^{-1}$ with $\left(\left|\omega / \sigma_{\omega}\right|\right)$ of 7.18000, while insignificant trends of no statistical significance is reported over desert regions in China [7]. In contrast, [8] has reported decreasing trends in various aerosol optical parameters over Cape Town, Bloemfontein, and Durban in South Africa due to implementation of environmental protection laws.

The reducing Saharan dust export from North Africa to Western and Atlantic regions has led to the observed negative trends of $-0.00400 \pm 0.00140 \mathrm{yr}^{-1}$ with $\left(\left|\omega / \sigma_{\omega}\right|\right)$ of 2.81 [9]. There is also a notable long-term seasonal pattern in both AOD and Ångström Exponent ( $\mathrm{E}$ ) over the West African region attributable to local climate [10] [11]. Additionally, this region is experiencing observable decreasing trends of dust aerosol due to decreasing dust activity i.e. $+0.22 \% \mathrm{yr}^{-1}$ at Banizoumbou, $-1.56 \% \mathrm{yr}^{-1}$ at Dakar and $-1.95 \% \mathrm{yr}^{-1}$ at Ouagadougou [11] [12] [13] [14] [15]. This result is consistent with the outcomes from the Global 
Aerosol Climatology Project (GACP) data [3]. Other than dust events, aerosol characteristics over the West Africa region are also modulated by biomass burning and emissions from agricultural activity during the dry season (December to January) [16]. Studies by [17] on AOD over Middle East Combined Dark Target/Deep Blue aerosol optical depth (AOD) satellite product of the moderateresolution imaging spectroradiometer (MODIS) collection 6 to study trends over the Middle East between 2000 and 2015. The study used multiple linear regression to show that AOD trends and interannual variability can be attributed to soil moisture, precipitation and surface winds.

Recent studies over the East African region show that aerosol characteristics are controlled directly by the local climate, i.e. Monsoonal precipitation [10]. This monsoon precipitation accelerates wet scavenging of aerosols from the atmosphere which explains the low AOD values during wet season [15] [18].

It is evident that accurate diagnosis of the regional aerosol influence on climate models requires long-term and accurate identification of aerosol sources and sinks. For example, over East Africa, aerosol source regions are greatly influenced either anthropogenically or naturally [19]. In the previous case, fine mode aerosols over urban, industrialized and densely populated regions (Nairobi and Kampala) are mainly due to gas-to particle conversion mechanism of aerosols (fossil fuel, industrial-vehicular emissions, biomass and refuse burning) [20]. Biomass burning and deforestation activities in the recent years have impacted highly on the regional aerosol loading that modulate climate e.g. the disappearance of Mount Kilimanjaro glaciers and the Mau Forest Complex [21] [22]. Moreover, the latter case constitutes mainly coarse mode aerosols from dust loading, farming and maritime conditions i.e. sea salt and spray aerosols (Malindi), Lake-land air mass exchange (Mbita) and long distance transport of aerosols from the Arabian Peninsula desert via Monsoon winds over Malindi [19].

These factors (i.e. anthropogenic and natural activities coupled with variable seasonality, aerosol complexities and their short lifetime) hamper the efforts to accurately quantify the influence of aerosols on climatic models. Therefore, the remedy to unscramble the paradox is to use long-term satellite measurements with appreciable accuracy to study decadal aerosol annual and seasonal trends in AOD and Ångström Exponent Anomaly ( $\mathrm{EA}$ ). In this way, we shall be in position to examine, understand and explain aerosol effects on regional weather and climate systems, as well as on air quality [3]. The current study reports the trends in both AOD (at $550 \mathrm{~nm}$ ) and $\AA E A$ (at $470-660 \mathrm{~nm}$ ) over selected sites of East Africa namely Nairobi $\left(1^{\circ} \mathrm{S}, 36^{\circ} \mathrm{E}\right)$, Mbita $\left(0^{\circ} \mathrm{S}, 34^{\circ} \mathrm{E}\right)$, Mau Forest Complex $\left(0.0-0.6^{\circ} \mathrm{S} ; 35.1-35.7^{\circ} \mathrm{E}\right)$, Malindi $\left(2^{\circ} \mathrm{S}, 40^{\circ} \mathrm{E}\right)$, Mount Kilimanjaro $\left(3^{\circ} \mathrm{S}\right.$, $\left.37^{\circ} \mathrm{E}\right)$ and Kampala $\left(0^{\circ} \mathrm{N}, 32.1^{\circ} \mathrm{E}\right)$ from 2000 to 2013 . The sites were chosen on the basis of dominance of anthropogenic influence and availability of AERONET stations that provide ground truthing of the satellite data used.

This paper provides a perspective of more than a decade (2000-2013) under- 
standing of East Africa's regional AOD and ÅEA trends utilizing Moderate Resolution Imaging Spectroradiometer (MODIS) spectral data the weighted least squares (WLS) fitting method. The AERONET AOD used in this work serves to provide ground truthing to the MODIS measurements used in the trend analysis. This study therefore forms the basis of regional climate change studies which is a subset to global climate change. Moreover, a quantitative knowledge of aerosol effects not only does it act as a subset to the establishment of aerosols' role in the observed climate change but also necessitates the prediction of future climate over the East African region.

\section{Materials and Methods}

\subsection{Seasons and Atmospheric Dynamics}

East Africa covers diverse land forms comprising of glaciated mountains, SemiArid, Plateaus and Coastal regions. The region also consists of inland plains together with forest covers which have been under threat of extinct in the recent past due to wood locking and deforestation [23]. Moreover, the region experiences a distinct bimodal rainfall pattern i.e. March-April-May-MAM and September-October-November-SON (wet season) characterized by low AOD values due to enhanced scavenging of aerosols [10] [24]. The bimodal rainfall pattern is influenced by the Inter Tropical Convergence Zone (ITCZ), global oceans, tropical high pressure systems (Mascarene, St. Helena, Azores and Arabian), tropical Monsoons and cyclones [10] [25]. On the contrary, high AOD values are noted during dry season i.e. December-January-February-DJF and June-July-AugustJJA. These high AOD values are associated with enhanced aerosol emission from desert and biomass burning events with reduced scavenging of aerosols from the atmosphere through dry deposition. The selection of the study sites with its details (see Table 1) was based on physical features that are known to profoundly modify aerosol characteristics in the immediate atmosphere and the availability of AERONET stations at some of the study sites for easier ground truthing as shown in Figure 1.

\subsection{Modis and Aeronet Observations}

MODIS is on board the Earth Observing System (EOS) namely, Terra and Aqua satellites operating at an altitude of $705 \mathrm{~km}$ [25] [26]. MODIS measures reflected solar radiance and terrestrial emission in 36 channels $(0.41-14.4 \mu \mathrm{m}$ wavelength range) with resolutions varying between $0.25-1 \mathrm{~km}$. Level-3 MODIS gridded atmosphere monthly global product "MOD08_M3" at spatial resolution of $1^{\circ} \times$ $1^{\circ}$ [27] was used to study trends in both AOD (at $550 \mathrm{~nm}$ ) and ÅEA (at 470 - 660 $\mathrm{nm}$ ) from 2000 to 2013 over the study sites. To ground truth the results from MODIS, a trend analysis of AErosol RObotic NETwork (AERONET) [28] AOD (Level 1.5-cloud screened) at similar wavelength but limited to within $\pm 30 \mathrm{mi}$ nutes of the MODIS Terra overpass time was utilized. Basically, the choice of an AERONET site was limited to: 


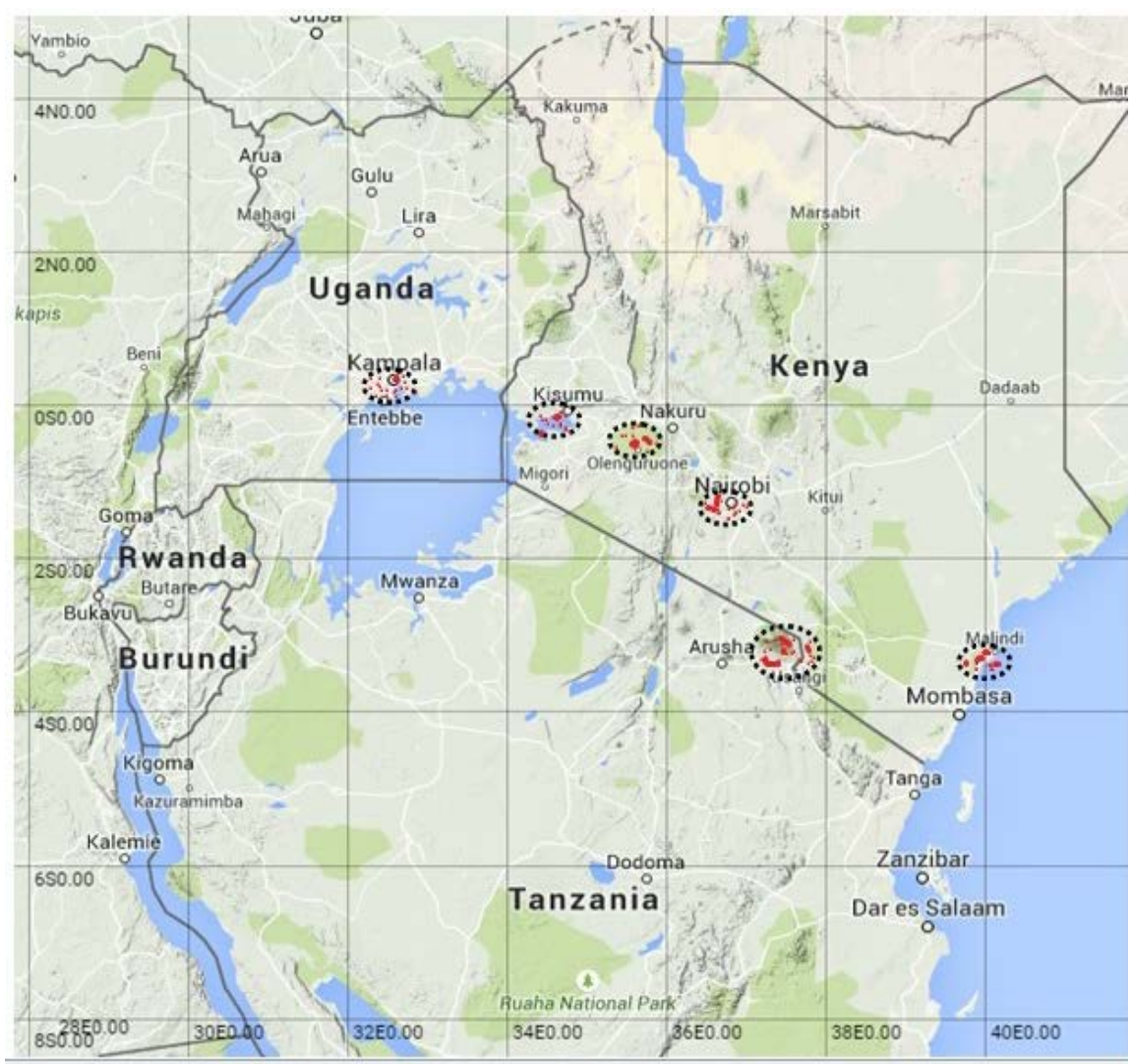

Figure 1. Study sites.

Table 1. Location, Prevailing environment and latest populace census over each study site in the East African atmosphere.

\begin{tabular}{|c|c|c|c|c|c|c|}
\hline \multirow{2}{*}{ Country } & \multirow{2}{*}{ Site of Study } & \multicolumn{2}{|c|}{ Location } & \multirow{2}{*}{$\begin{array}{l}\text { Altitude } \\
\text { (Meters) }\end{array}$} & \multirow{2}{*}{$\begin{array}{c}\text { Type of Prevailing } \\
\text { Environment }\end{array}$} & \multirow{2}{*}{$\begin{array}{l}\text { Populace as per } \\
\text { the latest census } \\
\text { (Year of census) }\end{array}$} \\
\hline & & Latitude & Longitude & & & \\
\hline \multirow{4}{*}{ Kenya } & Nairobi & $1.0^{\circ} \mathrm{S}$ & $36.0^{\circ} \mathrm{E}$ & 1798 & Urban & $3,138,369$ (2009) \\
\hline & Mbita & $0.0^{\circ} \mathrm{S}$ & $34.1^{\circ} \mathrm{E}$ & 1125 & Rural & 46,223 (2009) \\
\hline & Malindi & $2.3^{\circ} \mathrm{S}$ & $40.1^{\circ} \mathrm{E}$ & 12 & Maritime & $1,109,735$ (2009) \\
\hline & $\begin{array}{c}\text { Mau Forest } \\
\text { Complex }\end{array}$ & $(0.0-0.6)^{\circ}$ & $(35.1-35.7)^{\circ} \mathrm{I}$ & $1800-2700$ & Forest cover & $79,000(2009)$ \\
\hline Tanzania & $\begin{array}{c}\text { Mount } \\
\text { Kilimanjaro }\end{array}$ & $3.1^{\circ} \mathrm{S}$ & $37.2^{\circ} \mathrm{E}$ & 5895 & $\begin{array}{c}\text { Volcanic/Forest } \\
\text { cover }\end{array}$ & $1,640,087(2012)$ \\
\hline Uganda & Kampala & $0.0^{\circ} \mathrm{N}$ & $32.1^{\circ} \mathrm{E}$ & 1190 & Urban & $1,659,600(2011)$ \\
\hline
\end{tabular}

1) The AERONET site should have more than three complete years of observation history limited to within the span of the study.

2) To complete a yearly data set is composed of more than seven qualified monthly averages.

Although a minimum of three year time series is insufficiently short for a statistically significant trend analysis, aided in ground truthing of MODIS results. Thus following this criterion, Nairobi, Mbita and Malindi AERONET sites in Kenya were utilized. Since actual validation of MODIS AOD has been a subject 
of some work over the East Africa region [24] current study sought to compute the MODIS trend analysis in both AOD and ÅEA which is ground truthed by AERONET level 1.5 AOD data over selected sites based on the criterion stated above.

The MODIS products are retrieved based on aforementioned raw measurements following a lookup table approach in which a small set of aerosol types, loading and geometry are assumed to span the range of global aerosol conditions. The algorithm matches the measured spectral reflectance with the lookup table and theoretically retrieves the atmospheric scenario corresponding to the observed radiation field [25]. Details of periodical updates in the MODIS retrieval algorithm and the overall spectral imaging technique are discussed elsewhere [25] [26].

\subsection{Estimation of Annual and Seasonal Trends}

\subsubsection{Weighted Least Squares Regression}

The trends in AOD and ÅEA were then calculated following the weighted least squares (WLS) fitting method [5] [11] [29] [30]. This is because the WLS method (see Equation (1)) handles regression situations in which the data points are of varying quality [31].

$$
Y_{t}=\mu+\omega X_{t}+N_{t}, t=1,2, \cdots, T
$$

where $Y_{t}$ is the time series, $\mu$ is a constant term, $\omega$ is the magnitude of the trend per year $\left(X_{t}=\frac{t}{12}\right), \quad N_{t}$ is the residual on the straight line of fit, $t$ is the individual months of the time series, $n=\frac{T}{12}$ is the total number of years while $T$ is the total number of months. Since the uncertainty in absolute AOD and $\AA \mathrm{EA}$ is heteroskedastic, a weighted factor $\left(=\frac{1}{\sigma^{2}}\right.$, where $\sigma$ is the error in each individual AOD and $\AA E A$ absolute values) was used. For the AOD case, the predicted uncertainty is $\pm(0.05+0.15 \mathrm{AOD})$ over land [27] [32]. The weighted factors assigned to each individual monthly data set aid in eliminating the influence of either high or low AOD and ÅEA absolute values on the trend characteristics. The statistical significance of the calculated trends has been assessed using the WLS method described by [31]. It is shown that the uncertainty $\left(\sigma_{\omega}\right)$ on the estimated trend can be approximated by:

$$
\sigma_{\omega} \approx \frac{\sigma_{N}}{n^{3 / 2}} \sqrt{\frac{1+\phi}{1-\phi}}
$$

In Equation (2), $\sigma_{N}$ is the standard deviation of the residuals of $N_{t}$ on the fit while $\phi$ is the autocorrelation coefficient. When the absolute trend relative to its uncertainty i.e. $\left|\omega / \sigma_{\omega}\right|$ ratio is 2 or more, the trend is significant at $95 \%$ confidence level. Similarly, significance at the $90 \%$ level is found for $\left|\omega / \sigma_{\omega}\right|>1.65$ (the z-score of $10 \%$ point of the normal distribution). 


\subsubsection{Annual Trends}

Monthly data sets were computed by determining a simple mean of high quality assurance (QA) (2 or 3) daily retrievals of AOD and ÅE. Since the uncertainty in $\AA ̊$ cannot be globally quantified due to its observed unrealistic values and its binary behavior [25] [31]. ÅEA was computed by determining the difference between $\AA \mathrm{E}$ monthly variation and the average over all the years under consideration for each grid cell. Thus, utilizing the WLS method, the annual trend in both AOD and ÅEA was treated as a simple linear model that minimizes chisquare error statistics was adopted as shown in Equation (1). It is worth noting that the least squares fit described in Equation (1) was applied to both AOD and ÅEA time series to get the slope coefficient of the linear regression that represents the annual trend in each of the two optical properties.

\subsubsection{Seasonal Trends}

There is a strong seasonality in both emission intensities of natural and anthropogenic aerosols over the East African region [10]. Thus, a trend analysis was performed separately for each season i.e. Dry season (DJF and JJN) and Wet season (MAM and SON). AOD values used in the trend analyses over each site were averaged over a number of $1^{\circ} \times 1^{\circ}$ grids cells depending on the size of the site of interest. For a reasonable temporal distribution in the analysis and to maintain consistency with the estimation of the annual trends, seasonal trends were computed based on the time series of individual months for a particular season instead of calculating a seasonal mean trend i.e. the average between DJF and JJN for the dry season and MAM and SON for wet season from 2000 to 2013 over each site of study.

\section{Results and Discussions}

\subsection{Meteorological Influence on Aerosol Optical Depth}

Tropical Rainfall Measurement Mission (TRMM) derived rainfall rate (RR) $(\mathrm{mm} / \mathrm{hr})$ data at $0.25^{\circ} \times 0.25^{\circ}$ latitude longitude resolution from 2000 to 2013 are used in the study to examine corresponding correlation between monthly AOD and RR absolute values, if any, over the study sites. Before performing a correlation analysis, pre-treatment of the daily absolute values of AOD $\geq 1$ and their corresponding RR were excluded from the analysis. This was meant to increase the reliability of the monthly absolute values of the two products before correlation analysis. The annual RR trends (Table 2) were calculated in a similar way as the annual AOD trends. A negative correlation between monthly AOD and RR absolute values is noted in Figures 2(a)-(c). An increase in RR translates to a rise in aerosol scavenging from the atmosphere and the prevention of aerosol emissions from the wet surface, hence low AOD values over the study location. During dry periods, the residue varies freely due to aerosol emissions from deserts and biomass burning events. Moreover, reduced aerosol scavenging through dry deposition doesn't effectively remove aerosol particles from the atmosphere, leading to high AOD values over the study location. On the other 
Table 2. Annual trends for rainfall rates TRMM product over each study site from February 2000 to December 2013.

\begin{tabular}{|c|c|c|c|c|c|c|c|c|c|c|c|c|c|c|}
\hline \multirow{2}{*}{ Site of study } & \multicolumn{14}{|c|}{ Years of study } \\
\hline & 2000 & 2001 & 2002 & 2003 & 2004 & 2005 & 2006 & 2007 & 2008 & 2009 & 2010 & 2011 & 2012 & 2013 \\
\hline Nairobi & 0.0126 & -0.0079 & -0.0003 & 0.0033 & 0.0104 & -0.0035 & -0.0003 & -0.0078 & -0.0002 & 0.0052 & -0.0117 & 0.0052 & 0.0051 & -0.0021 \\
\hline Mbita & 0.0262 & -0.0098 & 0.0208 & 0.0038 & 0.0002 & -0.0143 & 0.0124 & -0.0059 & -0.003 & -0.0027 & -0.0023 & 0.0132 & 0.0029 & -0.0043 \\
\hline Malindi & 0.0007 & -0.0007 & 0.001 & 0.0029 & 0.0021 & 0.0008 & 0.0022 & 0.0014 & -0.0043 & 0.0058 & -0.0053 & 0.0014 & 0.0064 & 0.003 \\
\hline $\begin{array}{c}\text { Mau Forest } \\
\text { Complex }\end{array}$ & 0.0157 & -0.0038 & 0.0006 & 0.0058 & -0.0086 & -0.0056 & 0.0034 & -0.0069 & -0.0004 & 0.007 & -0.0154 & 0.006 & 0.0086 & -0.0027 \\
\hline $\begin{array}{c}\text { Mount } \\
\text { Kilimanjaro }\end{array}$ & 0.0083 & -0.0075 & -0.0083 & -0.0048 & -0.0064 & -0.006 & 0.0031 & -0.0052 & -0.0034 & 0.0036 & -0.0062 & 0.005 & 0.0003 & -0.0068 \\
\hline Kampala & 0.0026 & -0.0137 & -0.0025 & -0.0053 & 0.0011 & -0.0003 & 0.0015 & 0.0025 & 0.0111 & 0.0066 & 0.0085 & 0.0111 & 0.0154 & 0.0083 \\
\hline
\end{tabular}

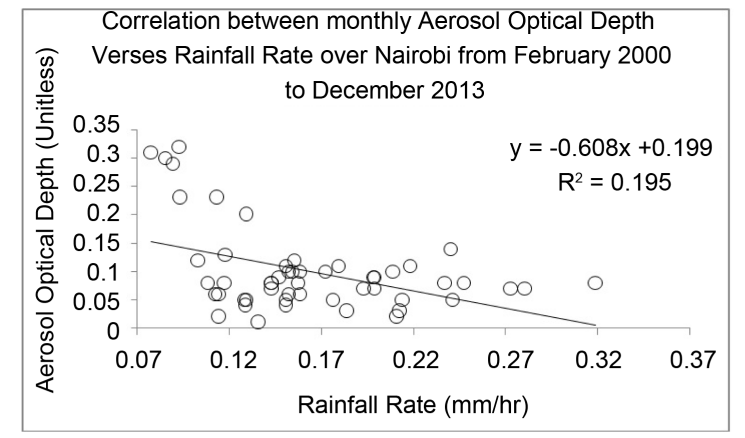

(a)

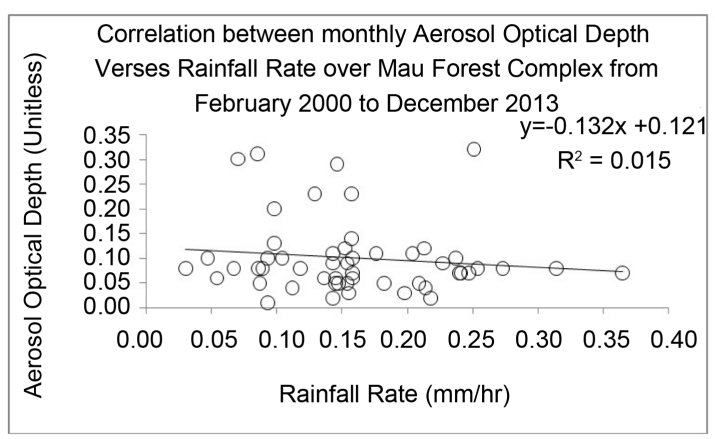

(c)

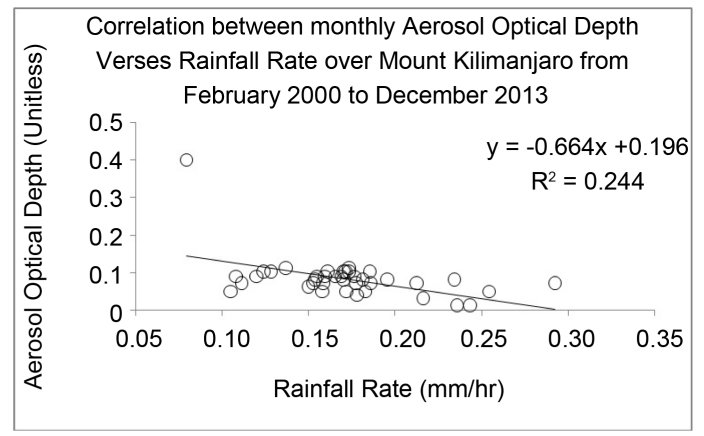

(b)

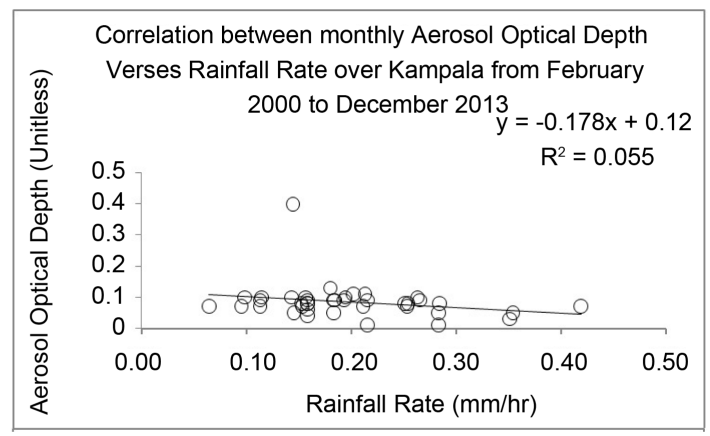

(d)

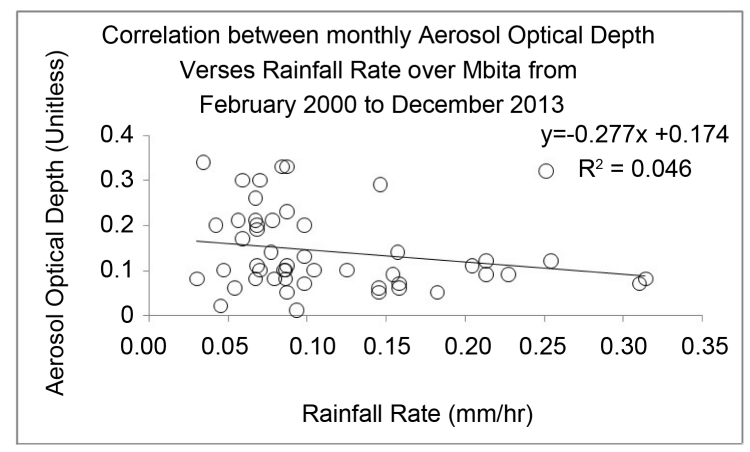

(e)

Figure 2. Correlations between monthly AOD verses Rainfall Rate (RR) (mm/hr) for the study period over Nairobi; (b) Correlations between monthly AOD verses Rainfall Rate (RR) ( $\mathrm{mm} / \mathrm{hr}$ ) for the study period over Mbita; (c) Correlations between monthly AOD verses Rainfall Rate (RR) (mm/hr) for the study period over Mau Forest Complex; (d) Correlations between monthly AOD verses Rainfall Rate (RR) ( $\mathrm{mm} / \mathrm{hr}$ ) for the study period over Kampala; (e) Correlations between monthly AOD verses Rainfall Rate (RR) ( $\mathrm{mm} / \mathrm{hr}$ ) for the study period over Mount Kilimanjaro. 
hand, there is no clear relationship between AOD and RR over Mount Kilimanjaro as noted in Figure 2(d) and Figure 2(e).

\subsection{Regional Trends}

\subsubsection{Trend Analysis of MODIS Terra and AERONET AOD (550 nm)}

Based on the criterion for the selection of an AERONET site, AOD level 1.5 data over Nairobi, Mbita and Malindi was utilized to compute a trend analysis of AOD for both AERONET (in Table 3) and MODIS Terra (in Table 4). The derived AERONET AOD trends were used to ground truth the MODIS AOD trends.

For similar years of study, both AERONET and MODIS Terra derived AOD trends over Nairobi and Mbita are consistent with each other. A comparison between AERONET and MODIS Terra derived AOD trends to not indicate any significant drift at all, thus, the use of MODIS Terra derived AOD in circumstances of missing data from AERONET is justified over the region. MODIS Terra AOD data over Malindi was of poor quality and was not included in this study. It is worthy pointing out that Malindi's AERONET AOD trends from 2008 to 2013 are controlled by monsoon precipitation as confirmed by [10]. Thus, a positive trend in AERONET AOD is as a result of a negative trend in RR trend and vice versa.

\subsubsection{Annual Trends of Aerosol Optical Depth and Ångström Exponent} Due to the limited AERONET AOD data that is insufficiently for a statistically significant trend analysis, the annual trends for both MODIS Terra AOD absolute values and ÅEA over the study sites were computed as shown in Table 4. The MODIS Terra AOD and ÅEA trend analysis were calculated from February 2000 to December 2013.

In general, the derived MODIS Terra AOD and ÅEA annual trends from 2000

Table 3. Annual AERONET AOD product trend over Nairobi, Mbita and Malindi (bold and italic for $95 \%$ significant and italic for $90 \%$ significant data).

\begin{tabular}{|c|c|c|c|c|c|c|c|c|c|c|c|}
\hline \multirow{2}{*}{ 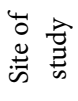 } & \multirow{2}{*}{ Product } & \multicolumn{10}{|c|}{ Years of study } \\
\hline & & & 2005 & 2006 & 2007 & 2008 & 2009 & 2010 & 2011 & 2012 & 2013 \\
\hline \multirow{3}{*}{ 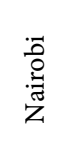 } & \multirow{3}{*}{ 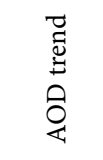 } & $\omega$ & -- & 0.0055 & 0.0086 & -0.0094 & 0.0031 & -- & -- & -- & -- \\
\hline & & $\sigma_{\omega}$ & -- & 0.0018 & 0.0022 & 0.0052 & 0.0012 & -- & -- & -- & -- \\
\hline & & $\left|\omega / \sigma_{\omega}\right|$ & -- & 3.06 & 3.91 & 1.81 & 2.58 & -- & -- & -- & -- \\
\hline \multirow{3}{*}{$\stackrel{\stackrel{\pi}{*}}{\sum^{2}}$} & \multirow{3}{*}{ 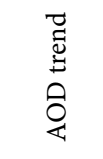 } & $\omega$ & -- & -- & -0.0091 & 0.0131 & -- & 0.0038 & -0.0024 & -0.0124 & -0.0029 \\
\hline & & $\sigma_{\omega}$ & -- & -- & 0.0032 & 0.0035 & -- & 0.0012 & 0.0010 & 0.0048 & 0.0011 \\
\hline & & $\left|\omega / \sigma_{\omega}\right|$ & -- & -- & 2.84 & 3.74 & -- & 3.17 & 2.40 & 2.58 & 2.64 \\
\hline \multirow{3}{*}{$\begin{array}{l}\ddot{z} \\
\stackrel{\Xi}{\pi}\end{array}$} & \multirow{3}{*}{ 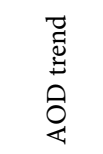 } & $\omega$ & -- & -- & -- & 0.0048 & -0.0079 & 0.0072 & -0.0086 & -0.0198 & -0.0036 \\
\hline & & $\sigma_{\omega}$ & -- & -- & -- & 0.0011 & 0.0012 & 0.0014 & 0.0023 & 0.0026 & 0.0013 \\
\hline & & $\left|\omega / \sigma_{\omega}\right|$ & -- & -- & -- & 3.91 & 6.58 & 5.14 & 3.74 & 7.62 & 2.77 \\
\hline
\end{tabular}


Table 4. Annual trends for MODIS AOD and ÅEA over the study sites from February 2000 to December 2013 (bold and italic for $95 \%$ significant and italic for $90 \%$ significant data).

\begin{tabular}{|c|c|c|c|c|c|c|c|c|c|c|c|c|c|c|c|c|}
\hline \multirow{2}{*}{ 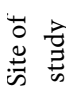 } & \multirow{2}{*}{ Product } & \multicolumn{15}{|c|}{ Years of study } \\
\hline & & & 2000 & 2001 & 2002 & 2003 & 2004 & 2005 & 2006 & 2007 & 2008 & 2009 & 2010 & 2011 & 2012 & 2013 \\
\hline \multirow{6}{*}{$\begin{array}{l}\tilde{\overrightarrow{0}} \\
\text { 节 } \\
\text { z }\end{array}$} & \multirow{3}{*}{ 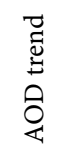 } & $\omega$ & -0.0025 & 0.0035 & 0.0011 & 0.0033 & -0.0026 & 0.0035 & 0.0035 & 0.0035 & 0.0035 & 0.0035 & 0.0035 & 0.0035 & 0.0035 & 0.0035 \\
\hline & & $\sigma_{\omega}$ & 0.0012 & 0.0015 & 0.0006 & 0.0015 & 0.0011 & 0.0015 & 0.0015 & 0.0015 & 0.0015 & 0.0015 & 0.0015 & 0.0015 & 0.0015 & 0.0015 \\
\hline & & $\left|\omega / \sigma_{\omega}\right|$ & 2.08 & 2.33 & 1.83 & 2.30 & 2.36 & 2.33 & 2.33 & 2.33 & 2.33 & 2.33 & 2.33 & 2.33 & 2.33 & 2.33 \\
\hline & \multirow{3}{*}{ 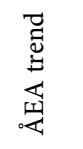 } & $\omega$ & 0.01 & -0.0015 & 0.0180 & 0.0089 & 0.0071 & -0.0015 & -0.0015 & -0.0015 & -0.0015 & -0.0015 & -0.0015 & -0.0015 & -0.0015 & -0.0015 \\
\hline & & $\sigma_{\omega}$ & 0.0034 & 0.0009 & 0.0040 & 0.0035 & 0.0026 & 0.0009 & 0.0009 & 0.0009 & 0.0009 & 0.0009 & 0.0009 & 0.0009 & 0.0009 & 0.0009 \\
\hline & & $\left|\omega / \sigma_{\omega}\right|$ & 2.94 & 1.67 & 4.50 & 2.54 & 2.73 & 1.67 & 1.67 & 1.67 & 1.67 & 1.67 & 1.67 & 1.67 & 1.67 & 1.67 \\
\hline \multirow{6}{*}{$\stackrel{\widetilde{\pi}}{\stackrel{\tilde{Z}}{\Sigma}}$} & \multirow{6}{*}{ 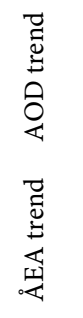 } & $\omega$ & -0.0023 & -0.0003 & -0.0024 & -0.0007 & -0.0038 & -0.0003 & -0.0003 & & -0.0003 & -0.0003 & & & & \\
\hline & & $\sigma_{\omega}$ & 0.0013 & 0.0001 & 0.0016 & 0.0003 & 0.0013 & 0.0001 & 0.0001 & 0.0001 & 0.0001 & 0.0001 & 0.0001 & 0.0001 & 0.0001 & 0.0001 \\
\hline & & $\left|\omega / \sigma_{\omega}\right|$ & 1.77 & 3.00 & 1.50 & 2.33 & 2.92 & 3.00 & 3.00 & 3.00 & 3.00 & 3.00 & 3.00 & 3.00 & 3.00 & 3.00 \\
\hline & & $\omega$ & -0.0135 & -0.0222 & -0.0138 & 0.0068 & -0.0128 & -0.0222 & -0.0222 & -0.0222 & -0.0222 & -0.0222 & -0.0222 & -0.0222 & -0.0222 & -0.0222 \\
\hline & & $\sigma_{\omega}$ & 0.0032 & 0.0035 & 0.0030 & 0.0027 & 0.0024 & 0.0035 & 0.0035 & 0.0035 & 0.0035 & 0.0035 & 0.0035 & 0.0035 & 0.0035 & 0.0035 \\
\hline & & $\left|\omega / \sigma_{\omega}\right|$ & 4.22 & 6.34 & 4.60 & 2.52 & 5.33 & 6.34 & 6.34 & 6.34 & 6.34 & 6.34 & 6.34 & 6.34 & 6.34 & 6.34 \\
\hline \multirow{6}{*}{$\begin{array}{l}\overrightarrow{\bar{Z}} \\
\stackrel{\Xi}{\Xi} \\
\bar{z}\end{array}$} & \multirow{6}{*}{ 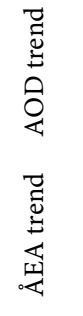 } & $\omega$ & 0.0034 & 0.0043 & -- & -- & -- & -- & -- & -- & -- & -- & -- & -- & -- & -- \\
\hline & & $\sigma_{\omega}$ & 0.0012 & 0.0019 & -- & -- & -- & -- & -- & -- & -- & -- & -- & -- & -- & -- \\
\hline & & $\left|\omega / \sigma_{\omega}\right|$ & 2.83 & 2.26 & -- & -- & -- & -- & -- & -- & -- & -- & -- & -- & -- & -- \\
\hline & & $\omega$ & -0.0024 & -0.038 & -- & -- & -- & -- & -- & -- & -- & -- & -- & -- & -- & -- \\
\hline & & $\sigma_{\omega}$ & 0.0013 & 0.0017 & -- & -- & -- & -- & -- & -- & -- & -- & -- & -- & -- & -- \\
\hline & & $\left|\omega / \sigma_{\omega}\right|$ & 1.85 & 2.24 & -- & -- & -- & -- & -- & -- & -- & -- & -- & -- & -- & -- \\
\hline \multirow{6}{*}{ 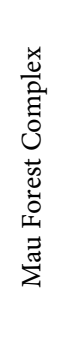 } & \multirow{3}{*}{ 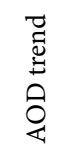 } & $\omega$ & -0.0021 & 0.0021 & 0.0001 & 0.0052 & -0.0024 & 0.0012 & 0.0045 & -0.001 & 0.0036 & 0 & 0.0043 & 0.0023 & & -0.0012 \\
\hline & & $\sigma_{\omega}$ & 0.0011 & 0.0014 & 0.0002 & 0.0017 & 0.0011 & 0.0010 & 0.0011 & 0.0007 & 0.0016 & 0.0009 & 0.0013 & 0.0011 & 0.0002 & 0.0006 \\
\hline & & $\left|\omega / \sigma_{\omega}\right|$ & 1.91 & 1.50 & 0.50 & 3.06 & 2.18 & 1.20 & 4.09 & 1.43 & 2.25 & 0.00 & 3.31 & 2.09 & 3.50 & 2.00 \\
\hline & \multirow{3}{*}{ 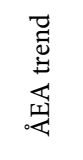 } & $\omega$ & -0.0066 & -0.0043 & 0.0124 & -0.0101 & 0.005 & -0.0168 & 0.0046 & -0.0079 & -0.0037 & 0.0132 & -0.0015 & 0.0007 & 0.0144 & 0.0036 \\
\hline & & $\sigma_{\omega}$ & 0.0022 & 0.0020 & 0.0028 & 0.0026 & 0.0025 & 0.0025 & 0.0027 & 0.0018 & 0.0031 & 0.0025 & 0.0008 & 0.0002 & 0.0031 & 0.0012 \\
\hline & & $\left|\omega / \sigma_{\omega}\right|$ & 3.00 & 2.15 & 4.43 & 3.88 & 2.00 & 6.72 & 1.70 & 4.39 & 1.19 & 5.28 & 1.88 & 3.50 & 4.65 & 3.00 \\
\hline \multirow{6}{*}{ 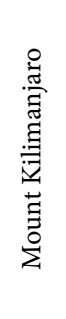 } & \multirow{3}{*}{$\begin{array}{l}\vec{Z} \\
\stackrel{\Xi}{\Xi} \\
0 \\
0 \\
0\end{array}$} & $\omega$ & -0.0152 & 0.0019 & 0.0008 & 0.0067 & -0.0085 & -0.0027 & 0.0066 & -0.0013 & 0.001 & -0.0049 & 0.0028 & 0.0005 & 0.0011 & -0.0091 \\
\hline & & $\sigma_{\omega}$ & 0.0022 & 0.0011 & 0.0002 & 0.0026 & 0.0018 & 0.0016 & 0.0015 & 0.0016 & 0.0006 & 0.0013 & 0.0014 & 0.0002 & 0.0009 & 0.0027 \\
\hline & & $\left|\omega / \sigma_{\omega}\right|$ & 6.91 & 1.73 & 4.00 & 2.58 & 4.72 & 1.69 & 4.40 & 0.81 & 1.67 & 3.77 & 2.00 & 2.50 & 1.22 & 3.37 \\
\hline & \multirow{3}{*}{ 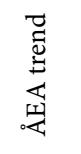 } & $\omega$ & 0.0022 & -0.0004 & 0.0004 & -0.0002 & -0.0002 & 0.0002 & 0.0005 & 0.0003 & -0.0003 & 0.0018 & -0.0007 & 0.003 & 0.0005 & 0.0012 \\
\hline & & $\sigma_{\omega}$ & 0.0003 & 0.0002 & 0.0002 & 0.0001 & 0.0004 & 0.0001 & 0.0002 & 0.0001 & 0.0001 & 0.0004 & 0.0003 & 0.0007 & 0.0002 & 0.0005 \\
\hline & & $\left|\omega / \sigma_{\omega}\right|$ & 7.33 & 2.00 & 2.00 & 2.00 & 0.50 & 2.00 & 2.50 & 300 & 3.00 & 4.50 & 2.33 & 4.29 & 2.50 & 2.40 \\
\hline \multirow{6}{*}{ 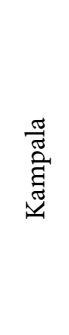 } & \multirow{6}{*}{ 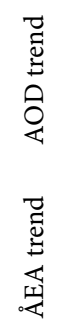 } & $\omega$ & -0.0029 & -0.0103 & -0.0116 & -0.0045 & -0.009 & -0.0029 & 0.0088 & 0.0011 & -0.0055 & -0.0026 & 0.0033 & -0.004 & -0.009 & -0.008 \\
\hline & & $\sigma_{\omega}$ & 0.0011 & 0.0024 & 0.0031 & 0.0026 & 0.0018 & 0.0017 & 0.0016 & 0.0009 & 0.0020 & 0.0016 & 0.0020 & 0.0019 & 0.0023 & 0.0024 \\
\hline & & $\left|\omega / \sigma_{\omega}\right|$ & 2.64 & 4.29 & 3.74 & 1.73 & 5.00 & 1.71 & 5.50 & 1.22 & 2.75 & 1.63 & 1.65 & 2.11 & 3.91 & 3.33 \\
\hline & & $\omega$ & 0.006 & 0.0176 & 0.0273 & 0.018 & 0.0152 & 0.0052 & 0.0089 & -0.002 & 0.0118 & 0.0112 & -0.0019 & 0.0019 & 0.0253 & 0.0263 \\
\hline & & $\sigma_{\omega}$ & 0.0023 & 0.0025 & 0.0046 & 0.0033 & 0.0037 & 0.0037 & 0.0031 & 0.0012 & 0.0035 & 0.0027 & 0.0012 & 0.0009 & 0.0061 & 0.0044 \\
\hline & & $\left|\omega / \sigma_{\omega}\right|$ & 2.61 & 7.04 & 5.93 & 5.45 & 4.11 & 1.41 & 2.87 & 1.67 & 3.37 & 4.15 & 1.58 & 2.11 & 4.15 & 5.98 \\
\hline
\end{tabular}


to 2013 were found to be either positively/negatively considerable but significantly modulated by the RR trends over each of the study site (see Table 2 and Table 4). From this observation, it is notable that aerosol optical characteristics over the East Africa region are controlled by monsoon precipitation. For example, Nairobi is dominated by positive annual trends in both AOD (except for 2000 and 2004) and ÅEA (except for 2001, 2005 and 2010) that may be are associated with increasing fossil fuel consumption, industrial-vehicular emissions, biomass and refuse burning over the metropolis city of East Africa for the period of study [19] [20]. The negative annual trends in AOD in 2000 and 2004 and ÅEA in 20012005 and 2010 may be associated with significant positive and drop in annual trends for RR respectively (see Table 2). Nairobi's annual trends in both AOD and ÅEA range between $\left(-0.0025 \pm 0.0012 \mathrm{yr}^{-1}\right.$ to $0.0081 \pm 0.0013$ $\mathrm{yr}^{-1}$ with $\left|\omega / \sigma_{\omega}\right|$ of range $\left.1.44-6.23\right)$ and $\left(-0.0015 \pm 0.0009 \mathrm{yr}^{-1}\right.$ to $0.0404 \pm$ $0.0092 \mathrm{yr}^{-1}$ with $\left|\omega / \sigma_{\omega}\right|$ of range 1.67 - 8.33) respectively for the period of study (see Table 4). From Table 4, most values of the derived annual trends for the two aerosol products are found to meet the statistical significance of $95 \%$ confidence level.

It is also evident from the results shown in Table 4 that, Mbita and Kampala are dominated by negative annual trends in AOD and ÅEA that are associated to increasing RR. Precisely, Mbita's annual trends in both AOD and ÅEA range between $\left(-0.0003 \pm 0.0001 \mathrm{yr}^{-1}\right.$ to $0.0036 \pm 0.0013 \mathrm{yr}^{-1}$ with $\left|\omega / \sigma_{\omega}\right|$ of range $1.50-3.00)$ and $\left(-0.0065 \pm 0.0028 \mathrm{yr}^{-1}\right.$ to $0.0086 \pm 0.0025 \mathrm{yr}^{-1}$ with $\left|\omega / \sigma_{\omega}\right|$ of range 1.86 - 8.07) respectively (see Table 4 ). This negative trend is related to increasing RR that hinders dust loading and biomass burning activities for agricultural land and enhances aerosol scavenging from the atmosphere [20] [24]. On the other hand, Kampala's annual trends in AOD and ÅEA varied between $\left(-0.0029 \pm 0.0011 \mathrm{yr}^{-1}\right.$ to $0.0088 \pm 0.0016 \mathrm{yr}^{-1}$ with $\left|\omega / \sigma_{\omega}\right|$ of range $\left.1.22-5.00\right)$ and $\left(-0.0019 \pm 0.0009 \mathrm{yr}^{-1}\right.$ to $0.0273 \pm 0.0046 \mathrm{yr}^{-1}$ with $\left|\omega / \sigma_{\omega}\right|$ of range $1.41-$ 7.04) respectively. Even though negative trends in AOD are noticeable over Kampala and modulated by $\mathrm{RR}$, there is a unique scenario over the site i.e. both AOD and RR trends are positively correlated in 2006, 2007 and 2010 due to high energy use and emissions associated with the growth of private motorized transport in Kampala city [33].

Mount Kilimanjaro's annual trends in AOD and ÅEA range between $(-0.0152$ $\pm 0.0022 \mathrm{yr}^{-1}$ to $0.0067 \pm 0.0026 \mathrm{yr}^{-1}$ with $\left|\omega / \sigma_{\omega}\right|$ of range $\left.0.81-6.91\right)$ and $\left(-0.0002 \pm 0.0001 \mathrm{yr}^{-1}\right.$ to $0.003 \pm 0.0007 \mathrm{yr}^{-1}$ with $\left|\omega / \sigma_{\omega}\right|$ of range $\left.0.50-7.33\right)$ respectively. These observed trends over the site are majorly modulated by dwindling RR (see Table 2) as a result of biomass burning and deforestation activities around the site [23]. Likewise, Mau forest complex experiences the dwindling RR (see Table 2) that are negatively correlated to the observed AOD annual trends. The observed annual trends in AOD and ÅA over the site range between $\left(-0.0007 \pm 0.0002 \mathrm{yr}^{-1}\right.$ to $0.0052 \pm 0.0017 \mathrm{yr}^{-1}$ with $\left|\omega / \sigma_{\omega}\right|$ of range $0.00-3.50)$ and $\left(-0.0168 \pm 0.0025 \mathrm{yr}^{-1}\right.$ to $0.0144 \pm 0.0031 \mathrm{yr}^{-1}$ with $\left|\omega / \sigma_{\omega}\right|$ of 
range 1.19 - 6.72) respectively (see Table 4). Negligible annual trends in the two aerosol products (see Table 4) of significant at the $95 \%$ confidence level is noted, therefore, aerosol characteristics over the site have relatively remained constant during the study period.

\subsubsection{Seasonal Trends of Aerosol Optical Depth}

MODIS AOD time series (see Figure 3) and seasonal trends together with their corresponding uncertainties for the said period of study over the sites are shown (see Table 5). It is notable that on average, except Nairobi, most of the study sites have negative trend in AOD for all seasons during the study period. This
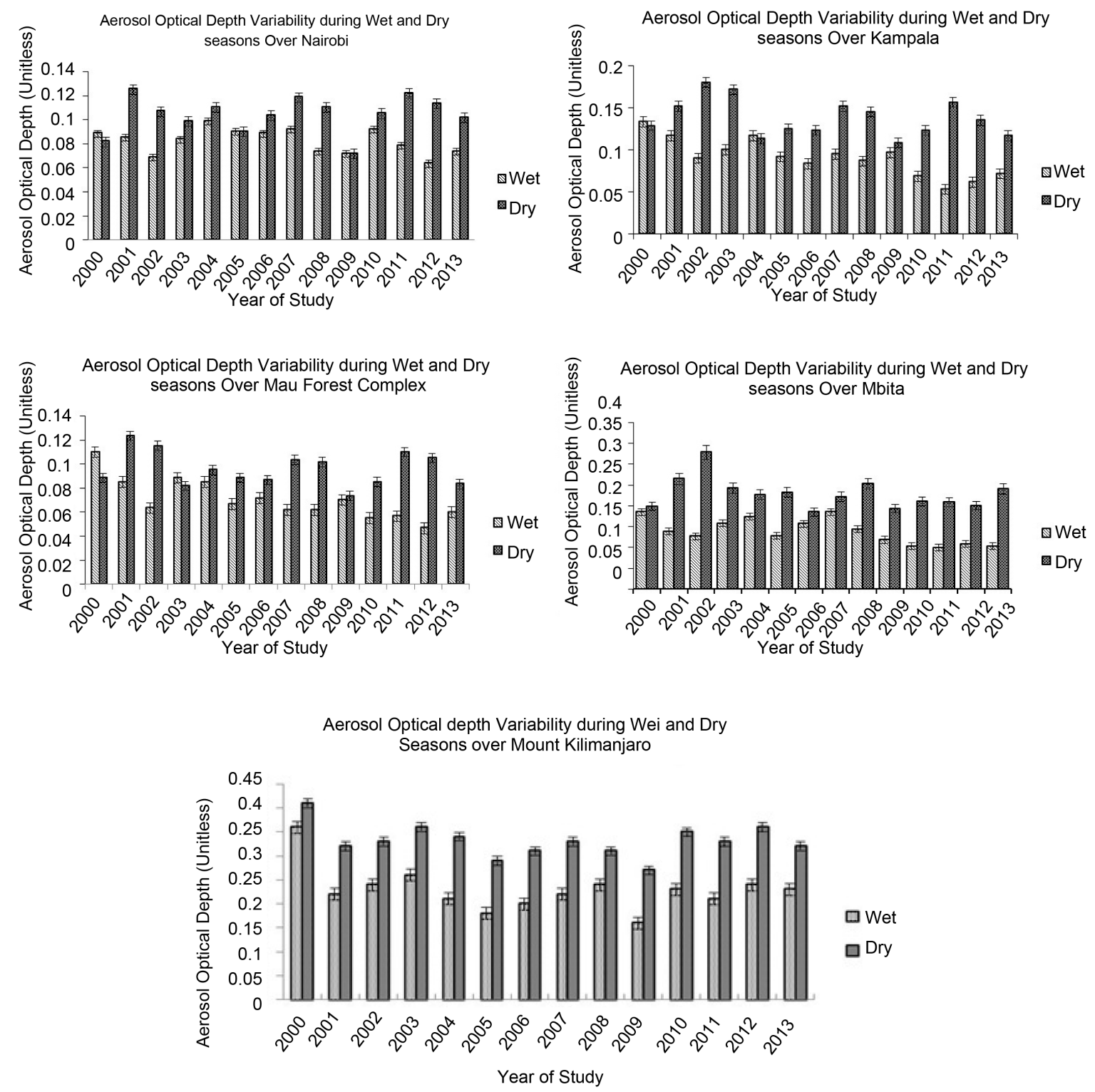

(e)

Figure 3. (a) Aerosol Optical Variability during wet and dry seasons over Nairobi; (b) Aerosol Optical Variability during wet and dry seasons over Mbita; (c) Aerosol Optical Variability during wet and dry seasons over Mau Forest; (d) Aerosol Optical Variability during wet and dry seasons over Kampala; (e) Aerosol Optical Variability during wet and dry seasons over Mount Kilimanjaro. 
Table 5. Seasonal MODIS Terra AOD trends over the study sites from February 2000 to December 2013 (bold and italic for 95\% significant and italic for 90\% significant data).

\begin{tabular}{ccccc}
\hline \multirow{2}{*}{ Site of study } & \multicolumn{2}{c}{ Dry season } & \multicolumn{2}{c}{ Wet season } \\
\cline { 2 - 5 } & $\omega \pm \sigma_{\omega}$ & $\left|\omega / \sigma_{\omega}\right|$ & $\omega \pm \sigma_{\omega}$ & $\left|\omega / \sigma_{\omega}\right|$ \\
\hline Nairobi & $0.0004 \pm 0.00021$ & 1.90 & $-0.001 \pm 0.00027$ & 3.70 \\
Mbita & $-0.0081 \pm 0.00058$ & 3.12 & $-0.0045 \pm 0.00058$ & 7.75 \\
Malindi & $-0.0007 \pm 0.00038$ & 1.87 & $-0.0032 \pm 0.00044$ & 7.32 \\
Mount Kilimanjaro & $-0.0034 \pm 0.00097$ & 3.51 & $-0.0049 \pm 0.00079$ & 6.23 \\
Kampala & $-0.0066 \pm 0.00013$ & $\mathbf{5 . 2 4}$ & $-0.0082 \pm 0.0015$ & $\mathbf{5 . 4 2}$ \\
\hline
\end{tabular}

negative trend was attributed to the transported pollution inlands since the region experiences dominant South Easterlies and North Easterlies during greater period of the year [24]. On the other hand, Nairobi's positive trend of $0.0004 \pm$ 0.00021 during the dry season (DJF and JJA) attributable to anthropogenic influences e.g. increasing populace, vehicular and industrial emissions [20]. During the wet season, each site of study experiences a higher magnitude of negative AOD trends as compared to the dry season (except Mbita) (see Table 5) significantly at between $90 \%$ to $95 \%$ range confidence levels. This is because of enhanced scavenging of aerosol particles in the atmosphere via rain washout and also minimized dust loading and wood locking during the wet season [24]. This result is similar to the results reported by [6] over West Africa region.

On the other hand, the negative trend observed for Mbita during the dry season is almost double that of the wet season as a result of decreasing biomass burning activities which have significantly decreased in frequency during the study period [19] [24]. Mau Forest complex shows an insignificant negative trend of $(-0.0007 \pm 0.00038)$ during the dry season that is attributable to continuing biomass burning and forest clearance for agricultural use even after the process of land reclamation that stated in 2008 [22]. However, for wet season, we note a significant negative trend of $(-0.0032 \pm 0.00044)$ as a result of limited dust loading and biomass burning during the study period. Likewise, Mount Kilimanjaro has been reclaimed in the recent past restraining the negative impacts of deforestation hence, explaining the negative seasonal trend in AOD during the study period [23].

\section{Conclusion}

Assessment of anthropogenic influence of atmospheric aerosols requires a comprehensive quantification of the temporal characteristics which significantly vary spatially. To aid in the quest to quantify aerosols effects on both regional and global climate change, we have reported on more than a decade trend analysis of aerosol optical properties over the region. MODIS Terra monthly AOD and ÅE level 3 data from February 2000 to December 2013 have been used to estimate annual trends (for both AOD and ÅEA) and seasonal trends (AOD only) over 
selected study sites of the East African region. Derived AERONET and MODIS Terra AOD trends were found to be consistent with each other, therefore the spectroscopic techniques can be used interchangeably particularly over scenarios where one of it has insufficient or poor quality data in the region. Monthly AOD and RR projected a negative correlation over the study sites except Kampala and Mount Kilimanjaro which showed no clear relationship that is attributable to aerosol cloud modulation that affect the RR received. Negative trends in aerosol loading over East Africa except Nairobi were associated to rain washout. Alike, Nairobi posted a positive trend due to anthropogenic influence from 2000-2013. Aerosol optical properties seasonal variability is evident during the study period. Future characterization of more radiative characteristics over the area of study is recommended.

\section{Acknowledgements}

This work was supported by the National Council for Science and Technology Grant funded by the Government of Kenya (NCST/ST \& I/RCD/4TH call PhD/ 201). The authors wish to thank the NASA Goddard Earth Science Distributed Active Archive for MODIS Level 3, TRMM rainfall data which served as a complement to the meteorological data from the Kenya Meteorological Department. The authors also wish to acknowledge the Brent Holben group for installing, maintaining and allowing the use of the optical data derived from their AERONET sun photometers.

\section{References}

[1] Solomon, S. (2007) Climate Change 2007-The Physical Science Basis: Working Group I Contribution to the Fourth Assessment Report of the IPCC (Vol. 4). Cambridge University Press, Cambridge.

[2] Stocker, T. (2014) Climate Change 2013: The Physical Science Basis: Working Group I Contribution to the Fifth Assessment Report of the Intergovernmental Panel on Climate Change. Cambridge University Press, Cambridge.

[3] Mishchenko, M.I., Geogdzhayev, I.V., Rossow, W.B., Cairns, B., Carlson, B.E., Lacis, A.A. and Travis, L.D. (2007) Long-Term Satellite Record Reveals Likely Recent Aerosol trend. Science, 315, 1543-1543. https://doi.org/10.1126/science.1136709

[4] Rosenfeld, D., Lohmann, U., Raga, G.B., O’Dowd, C.D., Kulmala, M., Fuzzi, S. and Andreae, M.O. (2008) Flood or drought: how do aerosols affect precipitation? Science, 321, 1309-1313. https://doi.org/10.1126/science.1160606

[5] Zhang, J. and Reid, J.S. (2010) A Decadal Regional and Global Trend Analysis of the Aerosol Optical Depth Using a Data-Assimilation Grade Over-Water MODIS and Level 2 MISR Aerosol Products. Atmospheric Chemistry and Physics, 10, 10949-10963. https://doi.org/10.5194/acp-10-10949-2010

[6] Hsu, N.C., Gautam, R., Sayer, A.M., Bettenhausen, C., Li, C., Jeong, M.J., Tsay, S.-C. and Holben, B.N. (2012) Global and Regional Trends of Aerosol Optical Depth over Land and Ocean Using SeaWiFS Measurements from 1997 to 2010. Atmospheric Chemistry and Physics, 12, 8037-8053. https://doi.org/10.5194/acp-12-8037-2012

[7] Ginoux, P., Prospero, J.M., Gill, T.E., Hsu, N.C. and Zhao, M. (2012) Global Scale Attribution of Anthropogenic and Natural Dust Sources and Their Emission Rates 
Based on MODIS Deep Blue Aerosol Products. Reviews of Geophysics, 50, No. 3. https://doi.org/10.1029/2012RG000388

[8] Kumar, R., Barth, M.C., Madronich, S., Naja, M., Carmichael, G.R., Pfister, G.G. and Sarangi, T. (2014) Effects of Dust Aerosols on Tropospheric Chemistry during a Typical Pre-Monsoon Season Dust Storm in Northern India. Atmospheric Chemistry and Physics, 14, 6813-6834. https://doi.org/10.5194/acp-14-6813-2014

[9] Kaskaoutis, D.G., Gautam, R., Singh, R.P., Houssos, E.E., Goto, D., Singh, S. amd Holben, B.N. (2012) Influence of Anomalous Dry Conditions on Aerosols over India: Transport, Distribution and Properties. Journal of Geophysical Research: Atmospheres, 117, No. D9. https://doi.org/10.1029/2011JD017314

[10] De Graaf, M., Tilstra, L.G., Aben, I. and Stammes, P. (2010) Satellite Observations of the Seasonal Cycles of Absorbing Aerosols in Africa Related to the Monsoon Rainfall, 1995-2008. Atmospheric Environment, 44, 1274-1283. https://doi.org/10.1016/j.atmosenv.2009.12.038

[11] Yoon, J., von Hoyningen-Huene, W., Kokhanovsky, A.A., Vountas, M. and Burrows, J.P. (2012) Trend Analysis of Aerosol Optical Thickness and Angstrom Exponent Derived from the Global AERONET Spectral Observations. Atmospheric Measurement Techniques, 5, 1271. https://doi.org/10.5194/amt-5-1271-2012

[12] Prospero, J.M. and Lamb, P.J. (2003) African Droughts and Dust Transport to the Caribbean: Climate Change Implications. Science, 302, 1024-1027. https://doi.org/10.1126/science.1089915

[13] Washington, R., Todd, M.C., Engelstaedter, S., Mbainayel, S. and Mitchell, F. (2006) Dust and the Low-Level Circulation over the Bodélé Depression, Chad: Observations from BoDEx 2005. Journal of Geophysical Research: Atmospheres, 111. https://doi.org/10.1029/2005JD006502

[14] Evan, A.T., Vimont, D.J., Heidinger, A.K., Kossin, J.P. and Bennartz, R. (2009) The Role of Aerosols in the Evolution of Tropical North Atlantic Ocean Temperature Anomalies. Science, 324, 778-781. https://doi.org/10.1126/science.1167404

[15] Reeves, C.E., Formenti, P., Afif, C., Ancellet, G., Attié, J.L., Bechara, J., Fierli, F., et al. (2010) Chemical and Aerosol Characterisation of the Troposphere over West Africa during the Monsoon Period as Part of AMMA. Atmospheric Chemistry and Physics, 10, 7575-7601. https://doi.org/10.5194/acp-10-7575-2010

[16] Johnson, B.T., Heese, B., McFarlane, S.A., Chazette, P., Jones, A. and Bellouin, N. (2008) Vertical Distribution and Radiative Effects of Mineral Dust and Biomass Burning Aerosol over West Africa during DABEX. Journal of Geophysical Research: Atmospheres, 113. https://doi.org/10.1029/2008JD009848

[17] Klingmüller, K., Pozzer, A., Metzger, S., Stenchikov, G.L. and Lelieveld, J. (2016) Aerosol Optical Depth Trend over the Middle East. Atmospheric Chemistry and Physics, 16, 5063-5073. https://doi.org/10.5194/acp-16-5063-2016

[18] Huang, J., Zhang, C. and Prospero, J.M. (2009) African Aerosol and Large-Scale Precipitation Variability over West Africa. Environmental Research Letters, 4, Article ID: 015006. https://doi.org/10.1088/1748-9326/4/1/015006

[19] Makokha, J.W. and Angeyo, H.K. (2013) Investigation of Radiative Characteristics of the Kenyan Atmosphere Due to Aerosols Using Sun Spectrophotometry Measurements and the COART Model. Aerosol and Air Quality Research, 13, 201-208.

[20] Van Vliet, E.D.S. and Kinney, P.L. (2007) Impacts of Roadway Emissions on Urban Particulate Matter Concentrations in Sub-Saharan Africa: New Evidence from Nairobi, Kenya. Environmental Research Letters, 2, Article ID: 045028.

https://doi.org/10.1088/1748-9326/2/4/045028 
[21] National Environmental Management Authority, Kenya (NEMA) (2013) Mau at a Glance. NEMA Report.

[22] Mutugi, M. and Kiiru, W. (2015) Biodiversity, Local Resource, National Heritage, Regional Concern, and Global Impact: The Case of Mau Forest, Kenya. European Scientific Journal, ESJ, 1, 681-691.

[23] Fairman, J.G., Nair, U.S., Christopher, S.A. and Moelg, T. (2011) Land Use Change Impacts on Regional Climate over Kilimanjaro. Journal of Geophysical Research: Atmospheres, 116. https://doi.org/10.1029/2010JD014712

[24] Ngaina, J.N., Mutai, B.K., Ininda, J.M. and Muthama, J.N. (2014) Monitoring Spatial-Temporal Variability of Aerosol over Kenya. Ethiopian Journal of Environmental Studies and Management, 7, 244-252. https://doi.org/10.4314/ejesm.v7i3.3

[25] Levy, R.C., Remer, L.A., Mattoo, S., Vermote, E.F. and Kaufman, Y.J. (2007) Second-Generation Operational Algorithm: Retrieval of Aerosol Properties over Land from Inversion of Moderate Resolution Imaging Spectroradiometer Spectral Reflectance. Journal of Geophysical Research: Atmospheres, 112. https://doi.org/10.1029/2006JD007811

[26] Remer, L.A., Kleidman, R.G., Levy, R.C., Kaufman, Y.J., Tanré, D., Mattoo, S., Holben, B.N., et al. (2008) Global Aerosol Climatology from the MODIS Satellite Sensors. Journal of Geophysical Research: Atmospheres, 113.

https://doi.org/10.1029/2007JD009661

[27] Ichoku, C., Kaufman, Y.J., Remer, L.A. and Levy, R. (2004) Global Aerosol Remote Sensing from MODIS. Advances in Space Research, 34, 820-827.

https://doi.org/10.1016/j.asr.2003.07.071

[28] Eck, T.F., Holben, B.N., Slutsker, I. and Setzer, A. (1998) Measurements of Irradiance Attenuation and Estimation of Aerosol Single Scattering Albedo for Biomass Burning Aerosols in Amazonia. Journal of Geophysical Research: Atmospheres, 103, 31865-31878. https://doi.org/10.1029/98JD00399

[29] Ramachandran, S., Kedia, S. and Srivastava, R. (2012) Aerosol Optical Depth Trends over Different Regions of India. Atmospheric Environment, 49, 338-347. https://doi.org/10.1016/j.atmosenv.2011.11.017

[30] De Meij, A., Pozzer, A. and Lelieveld, J. (2012) Trend Analysis in Aerosol Optical Depths and Pollutant Emission Estimates between 2000 and 2009. Atmospheric Environment, 51, 75-85. https://doi.org/10.1016/j.atmosenv.2012.01.059

[31] Weatherhead, E.C., Reinsel, G.C., Tiao, G.C., Meng, X.-L., Choi, D., Cheang, W.-K., Keller, T., DeLuisi, J., Wuebbles, D.J., Kerr, J.B., Miller, A.J., Oltmans, S.J. and Frederick, J.E. (1998) Factors Affecting the Detection of Trends: Statistical Considerations and Applications to Environmental Data. Journal of Geophysical Research, 103, 17149. https://doi.org/10.1029/98JD00995

[32] Li, Z., Zhao, X., Kahn, R., Mishchenko, M., Remer, L., Lee, K.-H., Wang, M., Laszlo, I., Nakajima, T. and Maring, H. (2009) Uncertainties in Satellite Remote Sensing of Aerosols and Impact on Monitoring Its Long-Term Trend: A Review and Perspective. In: Annales Geophysicae, Copernicus GmbH, 2755-2770. https://doi.org/10.5194/angeo-27-2755-2009

[33] Mabasi, T. (2009) Assessing the Impacts, Vulnerability, Mitigation, and Adaptation to Climate Change in Kampala City. 5 th Urban Research Symposium, Kampala. 